\title{
SORPTION BEHAVIOR OF FOUR TROPICAL WOODS USING A DYNAMIC VAPOR SORPTION STANDARD ANALYSIS SYSTEM
}

\author{
Merlin Simo-Tagne ${ }^{1, £}$, Romain Rémond $^{2}$, Yann Rogaume ${ }^{2}$, André Zoulalian $^{3}$, \\ Béguidé Bonoma ${ }^{4}$
}

\begin{abstract}
Sorption behavior of four tropical woods coming from Cameroon is studied using a Dynamic Vapor Sorption-Intrinsic apparatus. Sorption isotherms at $20^{\circ} \mathrm{C}$ and $40^{\circ} \mathrm{C}$ of Triplochiton scleroxylon (obeche), Entandrophragma cylindricum (sapele), Sterculia rhinopetala (lotofa) and Terminalia superba (frake also called limba) are compared to those in the literature with methods using saturated salts for lotofa and frake with satisfactory results. Experimental values are fitted using two sorption isotherm models. Sorption hysteresis is greatest in sapele and least in frake. When temperature increases, differences in the hysteresis of sorption among the woods decreases. Hystereses of all studied woods ranged from 0,5 to $3 \%$. Our studied woods have lower equilibrium moisture content probably caused by the higher values of extractives content. The water sorbed molecules on multilayer during both adsorption and desorption at $20^{\circ} \mathrm{C}$ and $40^{\circ} \mathrm{C}$ is greater in the case of frake and lower in the case of lotofa. The water sorbed molecules on multilayer of sapele is greater than those of obeche. The predominance of multilayer over monolayer of our woods is from 0,2 to 0,4 relative humidity in adsorption phase, and from 0,3 to 0,4 relative humidity in desorption phase.
\end{abstract}

Keywords: Adsorption, desorption, equilibrium moisture content, sorption isotherm, sorption hysteresis, tropical woods.

\section{INTRODUCTION}

It is well known that tropical countries have a lot of woods species. For example, Cameroonian forests have more than 300 woods species. These woods are used in many domains such as plywood, decorative veneers, interior joinery, furniture and packaging (Fernández et al. 2014).

The sorption isotherms are essential properties in the analysis and design of various biological material processes such as preservation, drying (Salin 2011), storing, packaging and mixing. It can be used to determine the net isosteric heat of sorption (Ouafia et al. 2015), for selecting appropriate storage conditions and packing systems that optimize or maximize the mechanical stability of biological material.

Deliiski (2011) presents wood sorption isotherms, but no specific data is given on each species. Jannot et al. (2006) use GAB and BET models to plot desorption isotherms and estimate specific areas of doussié, moabi, ebony, obeche and iroko at $20,30,40,50,60^{\circ} \mathrm{C}$. In the same temperatures previously cited, Bonoma and Simo-Tagne (2005) use Henderson and Chung-Pfost models to explain

'Post-Doctoral Position, LERMAB, ENSTIB, Epinal, France.

${ }^{2}$ University of Lorraine, LERMAB, ENSTIB, Epinal, France.

${ }^{3}$ University of Lorraine, LERMAB, Faculty of Sciences and Technologies, Nancy, France.

${ }^{4}$ University of Yaoundé I, Higher Teacher Training College, Applied Physic Laboratory, Yaoundé, Cameroon.

"Corresponding author: simotagne2002@yahoo.fr

Received: 16.07.2015 Accepted: 13.03. 2016 
the evolutions of equilibrium water content in the desorption phases of ebony and obeche with relative humidity. Simo-Tagne et al. (2011) present a correlation between equilibrium water content in function of temperature and relative humidity and estimate the isosteric heat of sorption of obeche and ebony using GAB model. Also, they studied the Soret effect on obeche for various temperatures. Fernández et al. (2014) determine the sorption isotherms and thermodynamic properties of frake and obeche at 15,35 and $50^{\circ} \mathrm{C}$.

In the literature, several authors use the standard static gravimetric method to determine the sorption isotherms (Ouafia et al. 2015). Description of this method is available on Jannot (2008). This method is so long to obtain an equilibrium state of the sample on a given conditions. Applied on wood material, the samples with $1 \mathrm{~mm}$ of thickness are often used and 30 to 40 days are necessary to obtain one equilibrium state (Jannot et al. 2006, Fernández et al. 2014, Esteban et al. 2004, De Palacios et al. 2012).

Simo-Tagne et al. (2016) have presented the experimental EMC, mass diffusivity coefficients and air permeability of these woods. Concerning the EMC, discussion between values obtained with DVS apparatus and others methods, the monolayer saturation moisture content, the modeling of the monomolecular water sorbed and the polymolecular water sorbed are not studied in Simo-Tagne et al. (2016).

The objectives of present work are: (1)To use DVS apparatus to determine and analyze the sorption isotherms (adsorption and desorption) of Triplochiton scleroxylon (obeche), Entandrophragma cylindricum (sapele), Sterculia rhinopetala (lotofa) and Terminalia superba (frake), four tropical woods most commercialized. (2)To deduce the hysteresis of sorption of each studied wood. (3)To study the behavior of water molecules in the scale of pore and (4) to compare the values obtained in this work by those obtained in the literature.

\section{MATERIALS AND METHODS}

\section{Materials Preparation}

All tests presented here have been done in the Studies and Research on Wood Material Laboratory (LERMAB) of University of Lorraine, located in Epinal, France.

As Engelund et al. (2010) and Jalaludin et al. (2009), isotherms were performed using a dynamic gravimetric water sorption analyzer from Surface Measurement Systems (DVS-Intrinsic) (Figure 1). Specimens were collected from natural forests of Douala Cameroon and from mature log. The specimens used were very fine wood-chips cut with a microtome blade to obtain samples on each board with dimensions approximately $1 \times 0,5 \times 2 \mathrm{~mm}$.

(a)

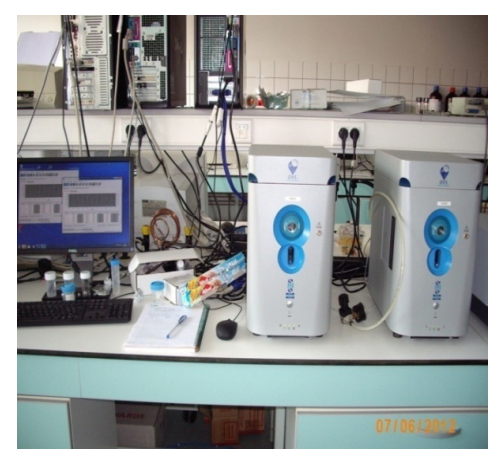

(b)

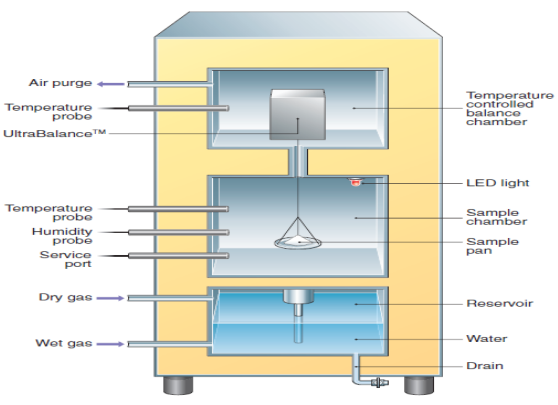

Figure 1. DVS apparatus used to measure different sorption isotherms. (a) Picture; (b) Schematic of the main components of the DVS intrinsic (Dynamic Vapor Sorption, surface measurement systems 2015). 


\section{Test Conditions}

The sample is weighted using a digital microbalance (total capacity of $1 \mathrm{~g}$; noise $<1 \mu \mathrm{g}$ ). Approximately $26 \mathrm{mg}$ of each sample were used for this measurement and two tests are made on each species. The sorption cycles applied in this work started from $0 \%$ relative humidity $(\mathrm{RH})$ to $90 \%$ $\mathrm{RH}$. The dry mass is determined at the end of this plateau. Isotherms were made at $20^{\circ} \mathrm{C}\left( \pm 0,02{ }^{\circ} \mathrm{C}\right)$ and $40^{\circ} \mathrm{C}\left( \pm 0,02{ }^{\circ} \mathrm{C}\right)$. Samples were maintained at a constant $\mathrm{RH}$ level until the weight change per minute $(\mathrm{dm} / \mathrm{dt})$ value reached $0,0005 \%$ per minute. Figure 2 is an example of evolutions of RH and weight change with the time in the case of sapele at $20^{\circ} \mathrm{C}$. We see that this experiment (adsorption and desorption) was made around $4500 \mathrm{~min}$. The raw DVS data was first analyzed using the DVS Standard Analysis System. This software permits construction of isotherm and hysteresis curves. For all samples, Equilibrium Moisture Content values were determined using the last fifteen data of each plateau.

\section{Sorption Analysis}

The Hailwood-Horrobin sorption model (HH-model) (Hailwood and Horrobin 1946) and the Guggenheim, Anderson and De Boer-Dent model (GAB-model) (Ouafia et al. 2015) are used for describing the envelope curves (desorption and adsorption isotherms from the extreme values $0 \%$ and $90 \%$ of $\mathrm{RH}$ ) because the agreement of the measured values with the computed isotherms are usually very good (Fernández et al. 2014, Popper et al. 2009). Mathematical equations of these models are briefly recalled on Table 1 .

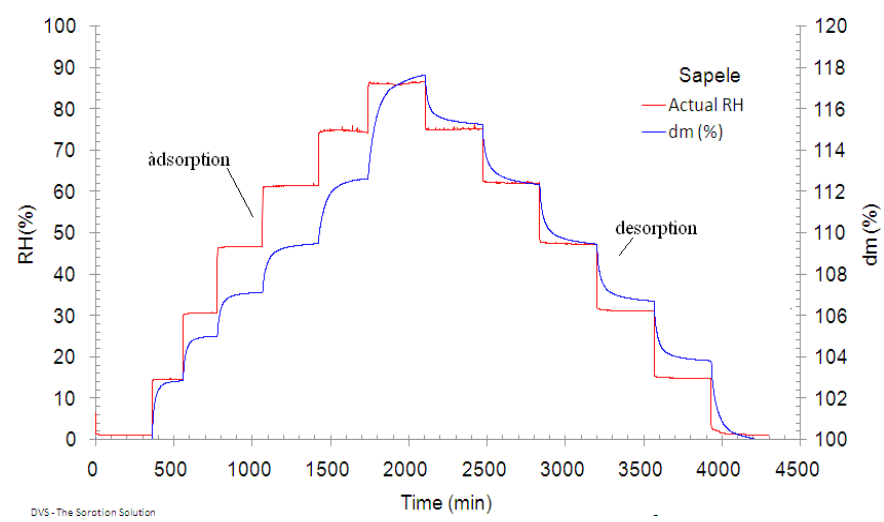

Figure 2. Air relative humidity and weight change versus time, Sapele, $20^{\circ} \mathrm{C}$.

Table 1. Equations used to model equilibrium desorption and adsorption isotherms.

\begin{tabular}{|c|c|}
\hline Names and References & Equilibrium moisture content model \\
\hline $\begin{array}{c}\text { HH-model } \\
\text { (Hailwood and Horrobin 1946) }\end{array}$ & $X_{e q}=\frac{K C X_{m} R H}{(1-K R H)(1-K R H+C \mathrm{~K} \mathrm{RH})}$ \\
\hline $\begin{array}{c}\text { GAB-model } \\
\text { (Ouafia } \text { et al. 2015) }\end{array}$ & $\frac{R H}{X_{e q}}=A+B R H-C_{0} R H^{2}$ \\
\hline
\end{tabular}

With:

$X_{e q}$ : Equilibrium moisture content $(\%) ; \mathrm{X}_{\mathrm{m}}$ : Monolayer saturation moisture content $(\%)$. The 
insignificant values of $\mathrm{X}_{\mathrm{m}}$ parameter may result from the weak presence of the active sorption sites available within the wood cell walls; C: Guggenheim constant (-) which corresponds to the total sorption heat of the first sorbed layer (Alix et al. 2009); K: Constant associated to water sorbed molecules on multi-layer (-) (Alix et al. 2009); RH: Water activity or Relative humidity on a scale of zero to one (-).

$\mathrm{A}, \mathrm{B}$ and $\mathrm{C}_{\mathrm{o}}$ are the shape factors. We can use these values to estimate the equilibrium between the activities of absorbed water and water vapor $\left(\mathrm{K}_{\mathrm{d}}\right)$, the equilibrium between the activity of hydrated wood over the activity of dry wood and absorbed water $\left(\mathrm{K}_{\mathrm{h}}\right)$ and the apparent molecular weight of wood per sorption site $\mathrm{W}_{\mathrm{i}}($ Dieste 2010). We have (Dieste 2010):

$$
\begin{aligned}
& K_{d}=\frac{50\left(-B+\sqrt{B^{2}+4 A C_{0}}\right)}{A} \\
& K_{h}=1+\frac{B\left(B+\sqrt{B^{2}+4 A C_{0}}\right)}{2 A C_{0}} \\
& W_{i}=1800 \sqrt{B^{2}+4 A C_{0}}
\end{aligned}
$$

A low $\mathrm{K}_{\mathrm{h}}$ implies a decrease in the activity of hydrated wood with respect to both the activities

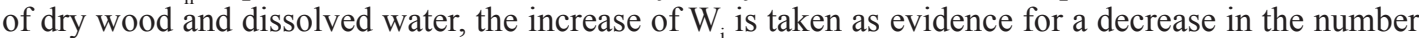
of active sorption sites. The HH model is composed into the adsorbed water or monomolecular water sorbed $\left(X_{h}\right)$ and the absorbed water or polymolecular water sorbed $\left(X_{d}\right)$. We have (Dieste 2010):

$$
\begin{aligned}
& X_{e q}=X_{h}+X_{d} \\
& X_{h}=\frac{1800 K_{d} K_{h} R H}{W_{i}\left(1+K_{d} K_{h} R H\right)} \\
& X_{d}=\frac{1800 K_{d} R H}{W_{i}\left(1-K_{d} R H\right)}
\end{aligned}
$$

$\mathrm{X}_{\mathrm{d}}$ in $\%, \mathrm{X}_{\mathrm{h}}$ in $\%$ and $X_{e q}$ in $\%$.

Monolayer moisture is the water within the cell wall that is associated closely with the $\mathrm{OH}$ groups, while polylayer water is when water occurs within the transient microcapillaries but is not intimately associated with the $\mathrm{OH}$ groups (Hill 2009).

The sorption isotherm fits were considered valid if the correlation coefficient $(\mathrm{R})$ was superior to 0,990 (Fernandez et al. 2014). The water taken up by the sample via monolayer sorption from $\mathrm{RH}_{\mathrm{m}}$ to $1 \mathrm{RH}$ is given by (Esteban et al. 2006):

$$
X_{u p}=X_{m}-X_{r e f}
$$

Where $\mathrm{X}_{\text {ref }}$ is the moisture content corresponding to $\mathrm{RH}_{\mathrm{m}}$ that gives the minimum of the derivative of equilibrium moisture content in relation to the RH. 


\section{RESULTS AND DISCUSSION}

Figure 3 presents the measured data obtained in this study at $20^{\circ} \mathrm{C}$ and $40^{\circ} \mathrm{C}$ respectively. It is clear that the sorption behavior of tropical species is different and apparatus used does not permit the obtaining an idea on the sorption behavior when water activity is above $90 \%$. But, during the conservation, storage and packaging of finished products, air relative humidity used are below $90 \%$. Both adsorption and desorption phase, obeche has higher equilibrium moisture content (EMC) values compared with others, frake has lower EMC. EMC of sapele is higher than the one of lotofa.

The temperature dependence of the EMC seems to be weak (Figure 3). This influence of temperature is conform to the results obtained by Rodriguez-Ramirez et al. (2011) and Björk and Rasmuson (1995). Also, we noticed that differences on our EMC are probably caused by the differences of extractive content, history of the sample, the wood structure and the part of the sample in the log.
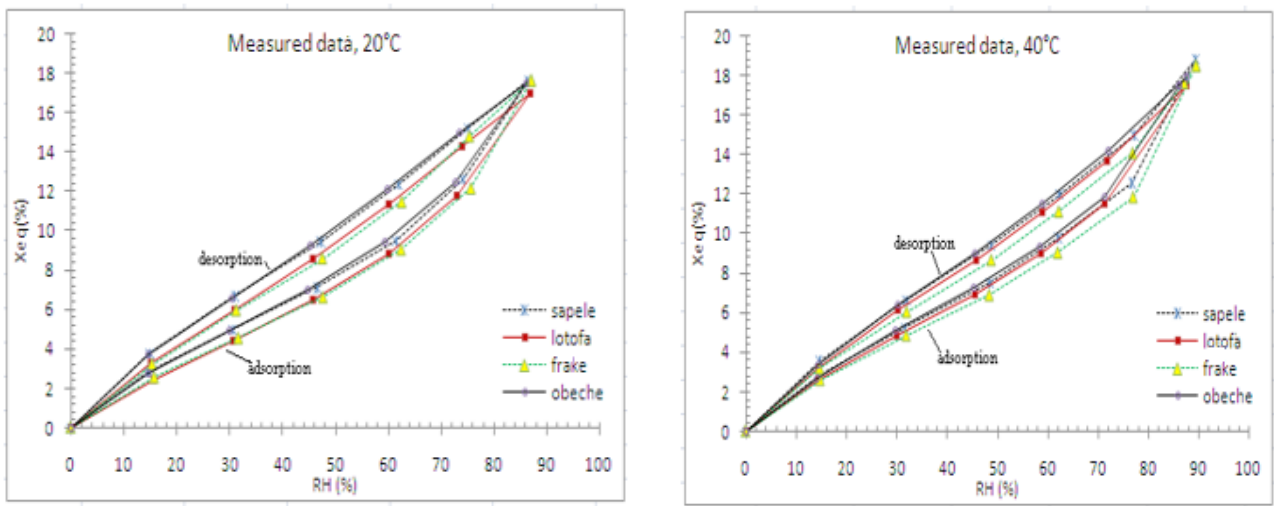

Figure 3. Measured data of sorption isotherms given by our DVS system.

Figures 4 and 5 present a comparison between results obtained in this work and those of the literature using standard static gravimetric method which requires a lot of time for reaching the hygroscopic equilibrium. On the Figure $4 \mathrm{a}$, we see that present results at $20^{\circ} \mathrm{C}$ are lower than those obtained by Fernández et al. (2014) at $15^{\circ} \mathrm{C}$, because EMC decreases when temperature increases (Esteban et al. 2004, Fernández et al. 2014, Jannot et al. 2006, Simo Tagne et al. 2011). But, we see a weak difference between present values and those obtained in the literature (Jannot et al. 2006, Simo-Tagne et al. 2011) on obeche at $20^{\circ} \mathrm{C}$ in desorption phases. It is probable that the origin, history of each sample used and natural variability from the species are the reason of this difference. Figure $4 \mathrm{~b}$ gives a good agreement between present results and those obtained in the literature (Jannot et al. 2006, Simo-Tagne et al. 2011) on obeche at $40^{\circ} \mathrm{C}$ in desorption phases. Figure 5 shows that our results at $20^{\circ} \mathrm{C}$ are lower than those obtained on the same wood species (frake) at $15^{\circ} \mathrm{C}$.

Figure 6 presents hysteresis of sorption given by present results. We see that at $20^{\circ} \mathrm{C}$, hysteresis of sorption are greater than those at $40^{\circ} \mathrm{C}$. Hysteresis increases when relative humidity increases. Tekleyohannes (1995) had obtained the same results. Sapele has higher hysteresis values compared with obeche. Frake has lower levels of sorption. When temperature increases, difference of the sorption hysteresis between our woods decreases. Also, we see that sorption hysteresis of studied woods are ranged from 0,5 to $3 \%$. 




(a)

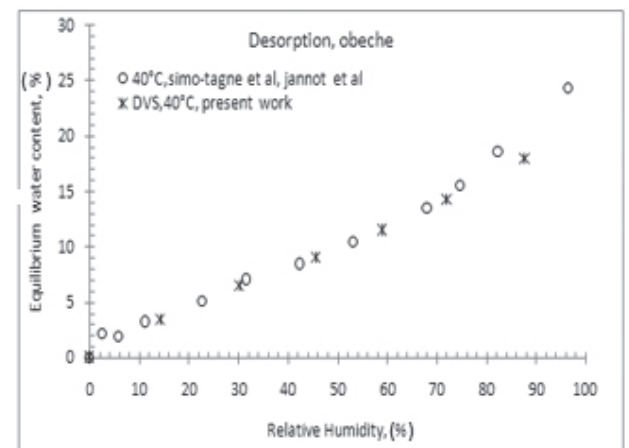

(b)

Figure 4. Desorption isotherms of obeche. (a) at 15 and $20^{\circ} \mathrm{C}$; (b) at $40^{\circ} \mathrm{C}$.

At a given air characteristic (temperature and relative humidity), studied woods have a near EMC.
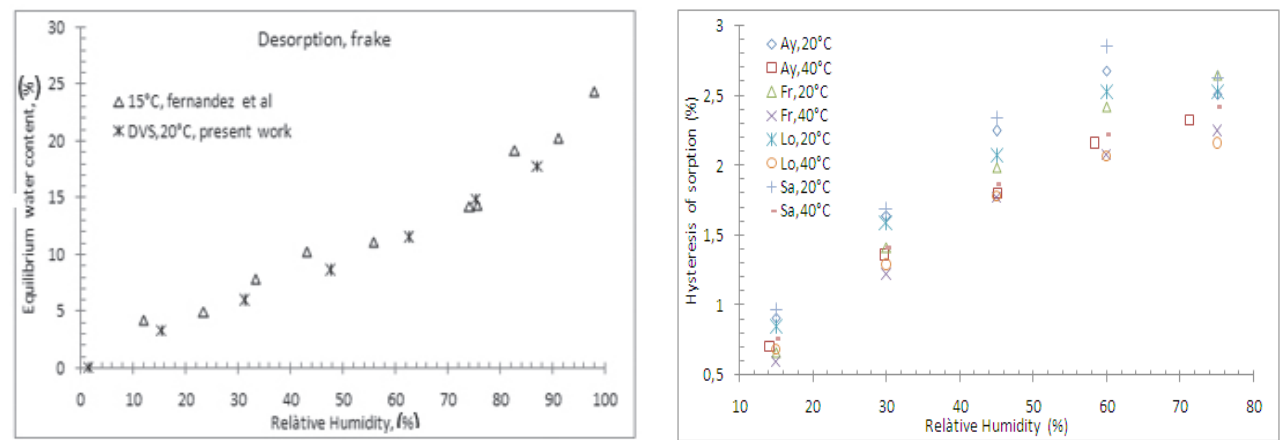

Figure 5. Desorption isotherms of frake at 15 and $20^{\circ} \mathrm{C}$.

Figure 6. Hysteresis of sorption of tropical woods Sa: Sapele; Lo: Lotofa; Fr: Frake; Ay: Obeche

Table 2 shows that intensities of correlation are greater than 0 ,9. Table 3 presents $\mathrm{K}_{\mathrm{d}}, \mathrm{K}_{\mathrm{h}}$ and $\mathrm{W}_{\mathrm{i}}$. We observe that both adsorption and desorption phases at $20^{\circ} \mathrm{C}$ and $40^{\circ} \mathrm{C}$, obeche has a low equilibrium between the activities of adsorbed water and water vapor $\left(\mathrm{K}_{\mathrm{d}}\right)$ and the one of frake is the great. The one of sapele is greater than the one of lotofa. Both adsorption and desorption at $20^{\circ} \mathrm{C}$ and $40^{\circ} \mathrm{C}$, lotofa has less accessibility for monolayer water $\left(\mathrm{K}_{h}\right.$ is weaker). Sapele has most accessibility for monolayer water $\left(\mathrm{K}_{\mathrm{h}}\right.$ is higher). Both adsorption and desorption, at $20^{\circ} \mathrm{C}$, frake has less accessibility for monolayer water compared of obeche, but at $40^{\circ} \mathrm{C}$, inverse is presented. Both adsorption and desorption phases at $20^{\circ} \mathrm{C}$ and $40^{\circ} \mathrm{C}$, frake has a great apparent molecular weight of wood per sorption site $\left(\mathrm{W}_{\mathrm{i}}\right)$ and obeche has the lower. At $20^{\circ} \mathrm{C}$, obeche has the great $\mathrm{W}_{\mathrm{i}}$ than lotofa. $\mathrm{K}_{\mathrm{d}}, \mathrm{K}_{\mathrm{h}}$ and $\mathrm{W}_{\mathrm{i}}$ increase with the temperature in desorption, but decrease with temperature in adsorption. Table 4 confirms that isotherms plotted are the type II sigmoid (because C $>2$ according to Esteban et al. (2004) and Fernandez et al. (2014)) and intensities of correlation are greater than 0,9 . We saw that monolayer saturation water content is greater in the case of desorption than the case of adsorption. As well as adsorption than desorption, the monolayer saturation moisture content $\mathrm{X}_{\mathrm{m}}$ is lower in the case of frake and higher in the case of obeche. $\mathrm{X}_{\mathrm{m}}$ of lotofa is greater than the one of sapele. 
Table 2. Identified parameters for $\mathrm{HH}$ sorption curves and intensity of correlation $\left(\mathrm{R}^{2}\right)$.

\begin{tabular}{|c|c|c|c|c|c|c|c|c|}
\hline \multirow{2}{*}{$\begin{array}{c}\text { Wood } \\
\text { species }\end{array}$} & \multicolumn{9}{|c|}{ Adsorption } & $\mathrm{A}$ model \\
\cline { 2 - 9 } & $\mathrm{A}$ & $\mathrm{B}$ & $\mathrm{C}_{\mathrm{o}}$ & $\mathrm{R}^{2}$ & $\mathrm{~A}$ & $\mathrm{~B}$ & $\mathrm{C}_{\mathrm{o}}$ & $\mathrm{R}^{2}$ \\
\hline \multicolumn{8}{|c|}{$20^{\circ} \mathrm{C}$} \\
\hline Lotofa & 5,302 & 8,405 & 9,878 & 0,998 & 4,094 & 4,259 & 3,621 & 0,933 \\
\hline Frake & 4,601 & 11,650 & 12,830 & 0,990 & 4,068 & 5,354 & 5,100 & 0,946 \\
\hline Sapele & 3,613 & 12,000 & 12,080 & 0,995 & 3,140 & 6,068 & 4,750 & 0,972 \\
\hline Obeche & 3,929 & 10,420 & 10,740 & 0,999 & 3,352 & 5,115 & 3,912 & 0,957 \\
\hline \multicolumn{8}{|c|}{$40^{\circ} \mathrm{C}$} \\
\hline Lotofa & 4,447 & 9,000 & 9,484 & 0,981 & 3,764 & 5,158 & 4,307 & 0,997 \\
\hline Frake & 4,028 & 12,420 & 12,600 & 0,935 & 3,679 & 7,152 & 6,489 & 0,980 \\
\hline Sapele & 3,646 & 11,190 & 10,940 & 0,939 & 3,188 & 6,805 & 5,641 & 0,992 \\
\hline Obeche & 4,034 & 9,280 & 9,319 & 0,981 & 3,554 & 5,028 & 4,006 & 0,995 \\
\hline
\end{tabular}

Table 3. Estimation $\mathrm{K}_{\mathrm{d}}, \mathrm{K}_{\mathrm{h}}$ and $\mathrm{W}_{\mathrm{i}}$ from identified parameters for $\mathrm{HH}$ sorption curves.

\begin{tabular}{|c|c|c|c|c|c|c|c|c|c|c|c|c|}
\hline \multirow[b]{3}{*}{$\begin{array}{l}\text { Wood } \\
\text { species }\end{array}$} & \multicolumn{6}{|c|}{ Adsorption } & \multicolumn{6}{|c|}{ Desorption } \\
\hline & \multicolumn{3}{|c|}{$20^{\circ} \mathrm{C}$} & \multicolumn{3}{|c|}{$40^{\circ} \mathrm{C}$} & \multicolumn{3}{|c|}{$20^{\circ} \mathrm{C}$} & \multicolumn{3}{|c|}{$40^{\circ} \mathrm{C}$} \\
\hline & $\mathrm{K}_{\mathrm{d}}$ & $\mathrm{K}_{\mathrm{h}}$ & $\mathrm{W}_{\mathrm{i}}(\mathrm{kg} / \mathrm{kmol})$ & $\mathrm{K}_{\mathrm{d}}$ & $\mathrm{K}_{\mathrm{h}}$ & $\begin{array}{c}\mathrm{W}_{\mathrm{i}} \\
(\mathrm{kg} / \mathrm{kmol})\end{array}$ & $\mathrm{K}_{\mathrm{d}}$ & $\mathrm{K}_{\mathrm{h}}$ & $\begin{array}{c}\mathrm{W}_{\mathrm{i}} \\
(\mathrm{kg} / \mathrm{kmol})\end{array}$ & $\mathrm{K}_{\mathrm{d}}$ & $\mathrm{K}_{\mathrm{h}}$ & $\begin{array}{c}\mathrm{W}_{\mathrm{i}} \\
(\mathrm{kg} / \mathrm{kmol})\end{array}$ \\
\hline Lotofa & 0,786 & 3,018 & 30127,11 & 0,765 & 3,646 & 28443,50 & 0,555 & 2,876 & 15839,65 & 0,585 & 3,342 & 17213,42 \\
\hline Frake & 0,830 & 4,053 & 34709,95 & 0,805 & 4,832 & 34022,74 & 0,641 & 3,054 & 19019,84 & 0,674 & 3,885 & 21797,34 \\
\hline Sapele & 0,810 & 5,104 & 32127,87 & 0,780 & 4,937 & 30374,97 & 0,598 & 4,232 & 17680,42 & 0,638 & 4,345 & 19573,05 \\
\hline Obeche & 0,793 & 4,343 & 29977,77 & 0,756 & 4,044 & 27680,81 & 0,560 & 3,727 & 15959,75 & 0,568 & 3,489 & 16322,55 \\
\hline
\end{tabular}

Table 4. Identified parameters for GAB sorption curves and intensity of correlation $\left(\mathrm{R}^{2}\right)$

\begin{tabular}{|c|c|c|c|c|c|c|c|c|}
\hline \multirow{2}{*}{$\begin{array}{c}\text { Wood } \\
\text { species }\end{array}$} & \multicolumn{9}{|c|}{ Adsorption } & \multicolumn{7}{c|}{ Desorption } \\
\cline { 2 - 10 } & \multicolumn{9}{|c|}{$\mathrm{X}_{\mathrm{m}}(\%)$} & $\mathrm{C}$ & $\mathrm{K}$ & $\mathrm{R}^{2}$ & $\mathrm{X}_{\mathrm{m}}(\%)$ & $\mathrm{C}$ & $\mathrm{K}$ & $\mathrm{R}^{2}$ \\
\hline \multicolumn{8}{|c|}{$20^{\circ} \mathrm{C}$} \\
\hline Lotofa & 6,02123048 & 3,97560688 & 0,780342 & 0,99534 & 9,85158182 & 4,13581965 & 0,636667 & 0,9881 \\
\hline Frake & 5,18791904 & 5,05352862 & 0,827875 & 0,98963 & 8,41998247 & 4,33013916 & 0,700698 & 0,98785 \\
\hline Sapele & 5,57780368 & 6,13328062 & 0,813057 & 0,99524 & 9,06574514 & 5,55060591 & 0,663477 & 0,99727 \\
\hline Obeche & 6,01201598 & 5,3317543 & 0,79179 & 0,99958 & 9,45324903 & 5,1000101 & 0,658499 & 0,99137 \\
\hline \multicolumn{8}{|c|}{$40^{\circ} \mathrm{C}$} \\
\hline Lotofa & 6,3223862 & 4,6569258 & 0,7649 & 0,98313 & 10,15549 & 4,529503 & 0,5865 & 0,9991 \\
\hline Frake & 5,2935741 & 5,8046786 & 0,8058 & 0,93656 & 8,903485 & 4,669546 & 0,6345 & 0,99578 \\
\hline Sapele & 5,959128 & 5,8808621 & 0,7755 & 0,94012 & 9,562488 & 5,272886 & 0,6136 & 0,99544 \\
\hline Obeche & 6,5164785 & 5,0407089 & 0,7560 & 0,98041 & 10,6308 & 4,5790 & 0,59 & 0,99703 \\
\hline
\end{tabular}

Figure 7 presents evolutions of measured and modeled EMC (during desorption and adsorption), also the monolayer sorption $\left(\mathrm{X}_{\mathrm{h}}\right)$ and polylayer water sorption $\left(\mathrm{X}_{\mathrm{d}}\right)$ applied on sapele $\left(\right.$ at $\left.40^{\circ} \mathrm{C}\right)$ and on lotofa $\left(\right.$ at $\left.20^{\circ} \mathrm{C}\right)$. The $\mathrm{HH}$ and $\mathrm{GAB}$ models seem to explain plausibly the sorption of water in wood. The monolayers are always greater in desorption than in adsorption and it is most affected by the sorption hysteresis. For this reason, $\mathrm{X}_{\mathrm{m}}$ obtained between adsorption and desorption are more different. The polylayers in desorption and in adsorption are near when RH is inferior of 0,7 . The monolayers sorption are reached at equilibrium moisture fractions in the range $0,04-0,06$ such as announced in the literature (Björk and Rasmuson 1995).

Figure 8 shows that the point of inflexion of the isotherm corresponds to a moisture content of 0,04 $\mathrm{kg} / \mathrm{kg}$ and occurs at $0,3 \mathrm{RH}$ in adsorption at $20^{\circ} \mathrm{C}$ (Figure 8a). This point of inflexion corresponds to a 
moisture content of $0,08 \mathrm{~kg} / \mathrm{kg}$ and occurs at $0,4 \mathrm{RH}$ in desorption at $20^{\circ} \mathrm{C}$ (Figure $8 \mathrm{~b}$ ). Beyond each of these points, multilayer sorption predominates over monolayer sorption. These findings indicate that, from 0,3 to $1 \mathrm{RH}$ (in adsorption) and from 0,4 to $1 \mathrm{RH}$ (in desorption), the water taken up by the samples via monolayer sorption is minimal, at only is ranged from 0,6 to $3,85 \%$ of the total (given in Table 5). Effectively, example given on Figura 8, shows that when EMC is higher than $\mathrm{X}_{\mathrm{m}}, \mathrm{X}_{\mathrm{h}}$ versus $\mathrm{RH}$ is not constant and vary slowly. At the given temperature, $X_{u p}$ is higher in desorption than in adsorption. Applied on the old wood of Pinus sylvestris, Esteban et al. (2006) indicate that in desorption, from 0,316 to $1 \mathrm{RH}$ the water taken up by the sample via monolayer sorption is minimal, at only $0,7 \%$ of the total.



(a)

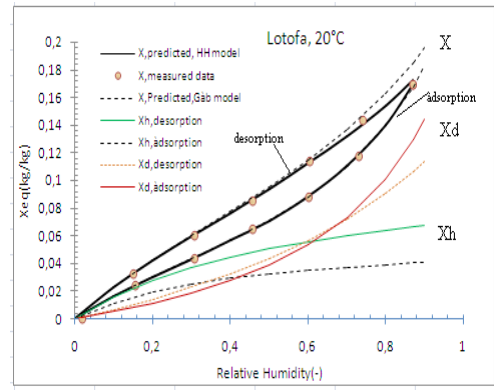

(b)

Figure 7. Sorption isotherms and deconvoluted adsorption-desorption curves fitted by the HH model, GAB model and measured data. (a) sapele at $40^{\circ} \mathrm{C}$; (b) lotofa at $20^{\circ} \mathrm{C}$

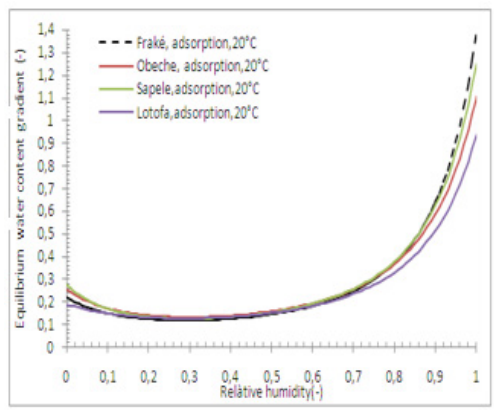

(a)



(b)

Figure 8. Equilibrium moisture content gradient versus relative humidity of our woods (a) adsorption, $20^{\circ} \mathrm{C}$; (b) desorption, $20^{\circ} \mathrm{C}$.

Table 5. Deduced $X_{u p}$.

\begin{tabular}{|c|c|c|c|c|}
\hline \multirow{2}{*}{$\begin{array}{c}\text { Wood } \\
\text { species }\end{array}$} & \multicolumn{4}{|c|}{$\mathrm{X}_{\text {up, } \%}$} \\
\cline { 2 - 5 } & \multicolumn{2}{|c|}{ Adsorption } & \multicolumn{2}{c|}{ Desorption } \\
\cline { 2 - 5 } & $\mathrm{T}=20^{\circ} \mathrm{C}$ & $\mathrm{T}=40^{\circ} \mathrm{C}$ & $\mathrm{T}=20^{\circ} \mathrm{C}$ & $\mathrm{T}=40^{\circ} \mathrm{C}$ \\
\hline Lotofa & 1,22 & 1,52 & 3,85 & 3,36 \\
\hline Frake & 0,69 & 0,79 & 1,12 & 1,71 \\
\hline Sapele & 0,78 & 0,76 & 0,97 & 0,96 \\
\hline Obeche & 0,61 & 1,12 & 1,06 & 2,23 \\
\hline
\end{tabular}

\section{CONCLUSIONS}

In this work sorption behavior of tropical woods applied on frake, obeche, lotofa and sapele is studied and analyzed using DVS-Intrinsic apparatus. The duration of each adsorption-desorption cycle 
is almost 4500min. DVS-Intrinsic apparatus gives satisfactory results on sorption isotherms of studied tropical woods. These sorption isotherms are well fitted with GAB and HH models and the results indicate a type II sigmoid shape for the EMC-RH curves, showing a decrease of the EMC with the increase of temperature, but with a weak influence. Sorption hysteresis most affects the monolayer saturation moisture content, the proof that the cycle desorption-adsorption most affects heat of sorption in the monolayer scale and briefly physical and chemical sorption properties in the scale of the pores. Monolayer saturation moisture content given by $\mathrm{X}_{\mathrm{m}}$ is always higher than the moisture content corresponding to $\mathrm{RH}_{\mathrm{m}}$ that gives the minimum of the derivative of EMC in relation to the $\mathrm{RH}$. By growth order of magnitude, active sorption sites available within the wood cell walls are frake, sapele, obeche and lotofa at $20^{\circ} \mathrm{C}$; frake, sapele, lotofa and obeche at $40^{\circ} \mathrm{C}$. Air temperature, air relative humidity and wood species affect the sorption behavior and sorption hysteresis of the tropical woods. The predominance of multilayer over monolayer of our woods is from 0,3 to $0,4 \mathrm{RH}$.

In a future work, it will interesting to study influences on sorption isotherms of extractives content, history of the sample, wood structure and the part of the sample in the log.

\section{ACKNOWLEDGEMENTS}

The principal author acknowledges the International Tropical Timber Organization (ITTO) for financial support (ITTO Ref. Number: 011/11A).

\section{REFERENCES}

Alix, S.; Philippe, E.; Bessadok, A.; Lebrun, L.; Morvan, C.; Marais, S. 2009. Effect of chemical treatments on water sorption and mechanical properties of flax fibres. Bioresource Technology 100:4742-4749.

Björk, H.; Rasmuson, A. 1995. Moisture equilibrium of wood and bark chips in superheated steam. Fuel 74 (12):1887-1890.

Bonoma, B.; Simo Tagne, M. 2005. A contribution to the study of the drying of ayous (Triplochiton scleroxylon) and of ebony (Diospyros ebenum). Phys Chem News 26:52-56.

Deliiski, N. 2011. Evaluation of wood sorption models and creation of precision diagrams for the equilibrium moisture content. Drvna Industrija 62(4):301-309.

De Palacios, P.; Estebán, L.G.; Fernández, F.G.; Garcia Iruelá, A.; Gonzáles Adrádos, J.R.; Conde, M. 2011. Comparative study of the $35^{\circ} \mathrm{C}$ sorption isotherms of cork stripped from the tree in 1968 and 2006. BioResources 6(2):2135-2144.

Dieste, A.; Krause, A.; Mai, C.; Militz, H. 2010. The calculation of EMC for the analysis of wood/water relations in Fagus sylvatica L. modified with 1,3-dimethylol-4,5-dihydroxyethyleneurea. Wood Sci Technol 44:597-606.

Engelund, E.T.; Klamer, M.; Venås, T.M. 2010. Acquisition of sorption isotherms for modified woods by the use of dynamic vapour sorption instrumentation: Principles and Practice. IRG/WP 1040518, 41 ${ }^{\text {st }}$ Annual Meeting, Biarritz, France, 9-13 May 2010.

Esteban, L.G.; Casasus, A.G.; De Palacios, P.; Fernandez, F.G. 2004. Saturated salt method determination of hysteresis of Pinus sylvestris L. wood for 35 degrees C isotherms. Mater Constr 54:51-64.

Esteban, L.G.; De Palacios, P.; Fernandez, F.G. ; Guindeo, A. ; Navarro, N. 2008. Thermodynamic characterization of particleboard using sorption isotherms. Wood Research 53(2):4556.

Esteban, L.G.; Fernandez, F.G. ; Guindeo, A.C. ; De Palacios, P.; Gril J. 2006. Comparison 
of the hygroscopic behaviour of 205-year-old and recently cut juvenile wood from Pinus sylvestris L. Annals of Forest Science 63(3):309-317.

Fernández, F.G.; De Palacios, P.; Esteban, L.G.; Iruela, A.G.; Gonzáles Adrádos, J.R.; López Álvarez, J.V. 2012. Sorption and thermodynamic properties of cork from the $35^{\circ} \mathrm{C}$ and $50^{\circ} \mathrm{C}$ isotherms. Bois et forêts des Tropiques 311(1):63-74.

Fernández, F.G.; Esteban, L.G.; De Palacios, P.; Cristina S.; Iruela A.G.; De la Fuente, J. 2014. Sorption and thermodynamic properties of Terminalia superb Engl. \& Diels and Triplochiton scleroxylon K. Schum. Through the 15, 35 and $50^{\circ} \mathrm{C}$ sorption isotherms. Eur. J. Wood Prod (72):99106.

Hailwood, A.J.; Horrobin, S. 1946. Absorption of water by polymers: analysis in terms of a simple model. Trans. Faraday Soc 42:84-92.

Hill, C.A.S.; Norton, A.; Newman, G. 2009. The water vapour sorption behaviour of natural fibers. Journal of Applied Polymer Science 11:1524-1537.

Jalaludin, Z.; Hill, C.; Kermani, A. 2009. Moisture adsorption isotherms of wood using dynamic vapor sorption. CTE, SEBE, Napier University, Edinburgh, UK.

Jannot, Y. 2008. Isothermes de sorption: modèles et détermination. 16 p.

Jannot, Y.; Kanmogne, A.; Talla, A.; Monkam, L. 2006. Experimental determination and modelling of water desorption isotherms of tropical woods: afzelia, ebony, iroko, moabi and obeche. Holz Roh-Werkst 64:121-124.

Ouafia, N.; Moghrani, H.; Benaouada, N.; Yassaa, N.; Maachi, R.; Younsi, R. 2015. Moisture sorption isotherms and heat of sorption of Algerian bay leaves (Laurus nobilis). Maderas. Ciencia y tecnología 17(4):759-772.

Popper, R.; Niemz, P.; Croptier, S. 2009. Adsorption and desorption measurements on selected exotic wood species. Analysis with the Hailwood-Horrobin model to describe the sorption hysteresis. Wood Research 54 (4):43-56.

Rodriguez, R.J.; Sandoval, T.S.; Mendez, L.L.; Carrillo, P.A. 2011. Experimental determination and modeling of equilibrium moisture content from the sapwood of Mexican pine (Pinus pseudostrobus Lindl.). For Stud China 13 (4):285-289.

Salin, J.G. 2011. Inclusion of the sorption hysteresis phenomenon in future drying models. Some basic considerations. Maderas. Ciencia y tecnología 13(2):173-182.

Simo-Tagne, M.; Remond, R.; Rogaume, Y.; Zoulalian, A.; Perré, P. 2016. Characterization of sorption behavior and mass transfer properties of four central africa tropical woods: ayous, sapele, frake, lotofa. Maderas. Ciencia y tecnología 18(1):207-226.

Simo-Tagne, M.; Zoulalian, A.; Njomo, D.; Bonoma, B. 2011. Modelisation of desorption isotherms and estimation of the thermophysic and thermodynamic properties of tropical woods in Cameroon: the case of Ayous and Ebony woods. Revue des Energies Renouvelables 14:487-500.

Surface Measurement Systems. 2015. DVS Intrinsic System Brochure. [on line], <www.smsuk. co.uk>, London, UK. [available the $6^{\text {th }}$ June 2015].

Tekleyohannes, A.T. 1995. Unified and heterogeneous modeling of water vapor sorption in Douglas-fir wood with artificial neural networks. Ph.D Thesis of the University of British Columbia. 